\title{
Idiopathic calcification of the ascending aorta and aortic valve in two young women ${ }^{1}$
}

\author{
Michael J. McLoughlin, Andre Pasternac, John Morch, and E. Douglas Wigle \\ From the Cardiovascular Unit, Department of Medicine, and Department of Radiology, Toronto General \\ Hospital, Toronto, Ontario, Canada
}

Two young women are described with extensive, dystrophic calcification of the ascending aorta and aortic valve. Both patients had mild aortic stenosis and one also had severe aortic insufficiency. In neither case was the aorta dilated. The cause of these unusual changes is unknown.

Extensive calcification of the ascending aorta is an unusual finding, and is almost always due to syphilis. Thus, it is frequently associated with dilatation of the ascending aorta, aneurysm formation, and aortic incompetence, and occurs predominantly in middleaged and older men.

In this report we describe the unusual combination of extensive tubular calcification of the nondilated ascending aorta associated with aortic valve calcification in two young women. The aetiology of these changes is unknown.

\section{Case I}

\section{Case reports}

An asymptomatic 17-year-old girl was referred to the Cardiovascular Unit of the Toronto General Hospital in August 1962 because a systolic murmur had been heard on routine physical examination. She was born prematurely and had had scarlet fever at age 5 without arthritis or cardiac involvement.

The only abnormal physical findings were a grade $3 / 6$ systolic ejection murmur best heard at the second right intercostal space, radiating towards the carotids and the apex, and a grade $\mathrm{r} / 6$ blowing early diastolic murmur along the left sternal border. The electrocardiogram was normal, and fluoroscopy showed a normal sized left ventricle, with some hyperactivity of the aorta in keeping with combined aortic stenosis and regurgitation.

She remained asymptomatic and was next seen again six years later in 1968. On physical examination, the blood pressure was $120 / 60 \mathrm{mmHg}$ and the arterial pulse had a slow upstroke but was increased in amplitude. The left ventricle was palpable at the 5 th left intercostal space between the mid-clavicular and anterior axillary line. The first and second heart sounds were normal. There

Received 4 June 1973.

1 This study was supported in part by a grant from the Ontario Heart Foundation. was a grade $4 / 6$ systolic ejection murmur at the right upper sternal border and a grade $2 / 6$ early diastolic murmur at the left sternal border.

The chest $x$-ray revealed moderate left ventricular enlargement. There was heavy calcification in the region of the aortic valve and of the ascending aorta, extending as far as the origin of the innominate artery (Fig. I). The electrocardiogram remained within normal limits.

All routine laboratory tests were normal, except for the erythrocyte sedimentation rate which was $21 \mathrm{~mm}$ in one hour. The serum cholesterol was $165 \mathrm{mg} / 100 \mathrm{ml}$, triglycerides $85 \mathrm{mg} / 100 \mathrm{ml}$, calcium $9.7 \mathrm{mg} / 100 \mathrm{ml}$, and phosphorus $3.4 \mathrm{mg} / 100 \mathrm{ml}$. Total serum proteins were $6.5 \mathrm{~g} / 100 \mathrm{ml}$, with 60 per cent albumin and 40 per cent globulin. The LE cell test was negative and the latex fixation test was non-reactive. VDRL and KRP were non-reactive, and the Treponema pallidum immobilization test was negative. $X$-rays of the sacroiliac joints were normal.

The patient underwent cardiac catheterization in September 1968. There was a peak systolic gradient of $38 \mathrm{mmHg}$ across the aortic valve with a cardiac index of $3.4 \mathrm{l}$./min per $\mathrm{m}^{2}$. The aortic pressure was $126 / 63 \mathrm{mmHg}$ and the left ventricular end-diastolic pressure varied from 12 to $17 \mathrm{mmHg}$. The aortic root cineangiogram showed a normal sized aorta and moderate to severe aortic regurgitation. All three aortic valve cusps showed diminished mobility with heavy calcification which extended into the ascending aorta. The left ventricular angiogram showed a dilated normally contracting left ventricle with a non-calcified and normally mobile mitral valve.

The patient is now aged 27. She complains occasionally of retrosternal tightness and of shortness of breath on exertion, but there are no objective findings of left ventricular failure.

\section{Case 2}

A 20-year-old girl was referred because she was found to have a systolic murmur on routine physical examina- 


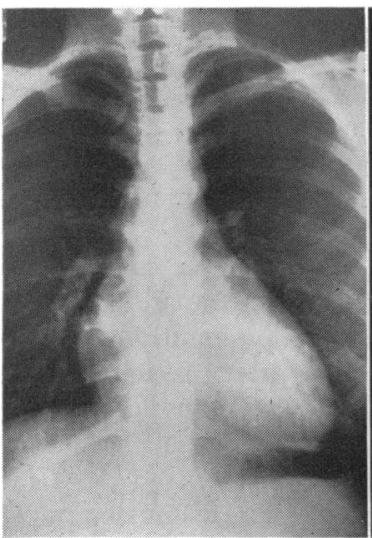

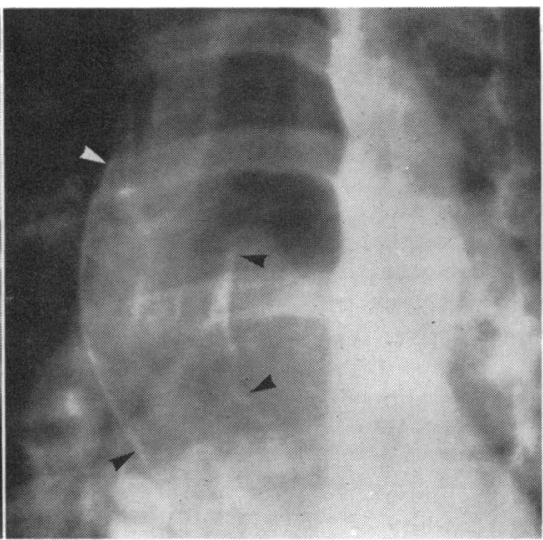

$b$

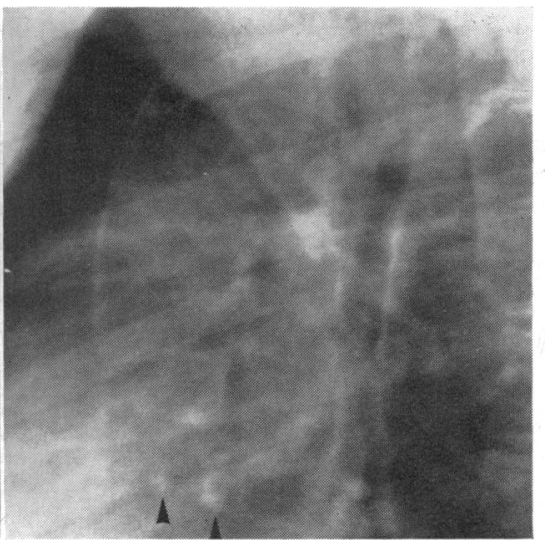

FIG. I (Case I) Posteroanterior, left anterior oblique, and lateral $\mathrm{x}$-rays show moderate enlargement of the left ventricle, and heavy calcification throughout the non-dilated, ascending aorta and in the aortic valve (arrows).

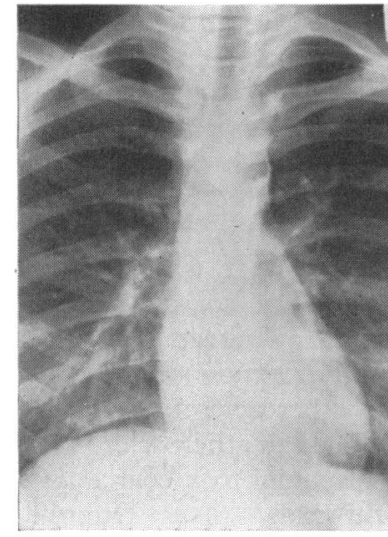

a

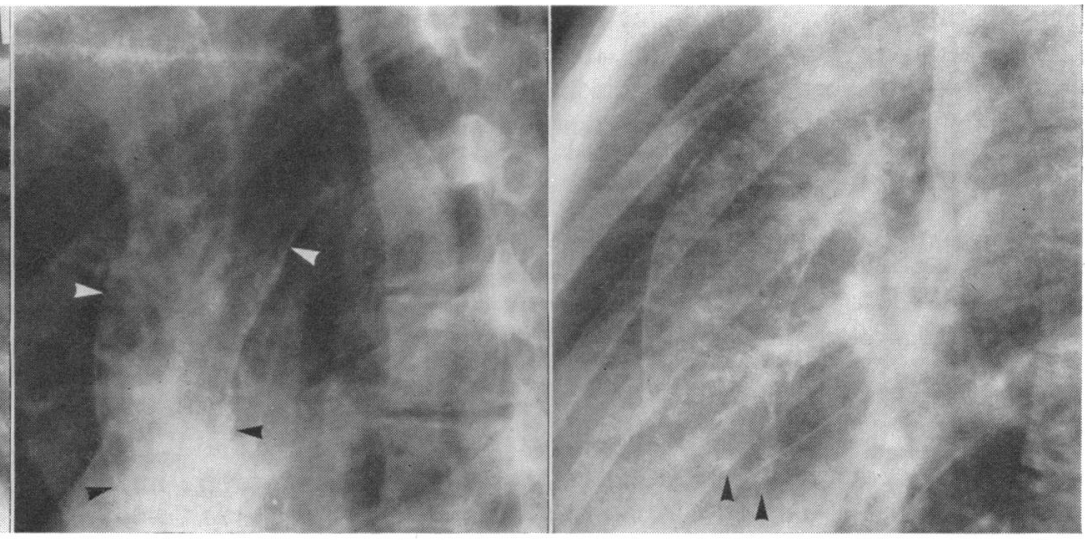

$b$

c

FIG. 2 (Case 2) Over penetrated, posteroanterior, left anterior oblique and lateral $\mathrm{x}$-rays show mild left ventricular enlargement and extensive calcification in the non-dilated ascending aorta and aortic valve, almost identical with that in Case I (arrows).

tion in December r971. She had complained of episodes of palpitation on exertion but was otherwise asymptomatic. She had had correction of bilateral hallux valgus deformities at age 13, and no cardiac abnormality was detected at that time. Because of ectodermal dysplasia, her secondary teeth, on erupting, tended to loosen and fall out. At age I6, her remaining teeth were extracted and she was fitted with upper and lower dentures. There was a family history of hallux valgus affecting her mother, maternal aunt, and maternal grandfather. Her mother had also had a neurofibroma removed from her neck. Three cousins had heart murmurs.
On physical examination, the heart rate was 84 per $\mathrm{min}$, and the blood pressure $100 / 65 \mathrm{mmHg}$. There was a right ventricular impulse at the left lower sternal border and a left ventricular impulse in the fifth left intercostal space at the mid-clavicular line. The heart sounds were normal. A very musical, vibratory, early systolic ejection murmur, grade $3 / 6$, was heard at the right and left upper sternal borders and radiated towards the carotids and the apex. There was no diastolic murmur.

Chest $x$-rays showed slight left ventricular enlargement with extensive calcification of the ascending aorta and aortic valve (Fig. 2). The electrocardiogram showed 
sinus rhythm, a QRS of $110^{\circ}$, and decreased anterior potentials.

All routine laboratory tests were normal except that the VDRL was reactive at a quantitative level of $I: 2$ while the KRP was non-reactive. The Treponema pallidum immobilization test was negative. Serum cholesterol was $135 \mathrm{mg} / \mathrm{ro0} \mathrm{ml}$, triglycerides $85 \mathrm{mg} / 100 \mathrm{ml}$, calcium $9.7 \mathrm{mg} / 100 \mathrm{ml}$, and phosphorus $4.1 \mathrm{mg} / 100 \mathrm{ml}$. Total serum protein was $7.2 \mathrm{~g} / 100 \mathrm{ml}$, with 45 per cent albumin and 55 per cent globulin. The LE cell test was negative and the latex fixation test was non-reactive. $X$-rays of the sacroiliac joints were normal.

At cardiac catheterization there was a peak systolic gradient of $21 \mathrm{mmHg}$ across the aortic valve with a cardiac index of $2.24 \mathrm{l} . / \mathrm{min}$ per $\mathrm{m}^{2}$. The aortic root angiogram showed a stiff, tricuspid aortic valve. There was calcification of the aortic valve and of the ascending aorta extending as far as the origin of the innominate artery. There was no evidence of aneurysm formation and no aortic regurgitation.

\section{Discussion}

The most remarkable finding in these patients was extensive calcification localized to the ascending aorta, distinctly visible on radiological examination. The aortas were not dilated and the calcification also involved the aortic valves which were tricuspid. In both patients aortic stenosis was demonstrated at cardiac catheterization, though in one aortic regurgitation was predominant. One patient had a mild increase in the erythrocyte sedimentation rate and the other had hypergammaglobulinaemia and a positive VDRL test on two occasions, though the Treponema pallidum immobilization test was negative.

In these patients, a large number of diseases which may affect the ascending aorta must be considered. Radiologically demonstrable calcification in the ascending aorta has been described in syphilis and atherosclerosis, and very rarely in cystic medial necrosis and Takayasu's disease. We have also considered the aortopathies occasionally associated with rheumatoid arthritis, ankylosing spondylitis, and other collagen diseases, and idiopathic medial aortopathy (Marquis et al., 1968), though calcification in the ascending aorta has not been described in these conditions.

By far the commonest cause of calcification in the ascending aorta is syphilitic aortitis, even at the present time when the incidence of cardiovascular syphilis is much reduced. It has been found in between 14.4 and 57 per cent of patients with luetic aortitis (Jackman and Lubert, 1945; Leighton, 1948; McCann and Porter, 1956; Smith and Leonard, 1959; Thorner and Carter, 1948; Wolkin, 1954). The calcification may involve the whole of the thoracic aorta but is more prominent in the ascend- ing portion and may be confined to this region. The calcification is intimal and occurs in atherosclerotic plaques secondary to the aortitis (Smith and Leonard, 1959; Wolkin, 1954). When calcification is extensive the ascending aorta is almost invariably dilated and, while aortic incompetence is common, stenosis does not occur.

The ascending aorta may also be calcified in atherosclerosis (Cohen, 1970), but the arch and descending thoracic aorta are predominantly involved. Calcification in the ascending aorta is uncommon even in patients with advanced atherosclerosis and was found in only 3.2 per cent of such patients in one series (Jackman and Lubert, 1945).

A most unusual patient in whom extensive calcification was ascribed to atherosclerosis has been reported (Flynn and Kattus, 1959; O'Sullivan and Glenn, 1955; Steinberg, 1966). She was 21 years of age when first seen and was diagnosed as coarctation of the aorta. The ascending aorta was moderately dilated and extensively calcified, the calcification extending into the aortic arch. She later developed aortic regurgitation but aortic valve calcification was not documented. This patient eventually came to surgery at age 28 . On opening the aorta distal to the left subclavian artery the lumen was almost completely obstructed over a short length by calcific atherosclerotic intimal thickening. This material was removed by endarterectomy and the thinned aortic wall in this region was reinforced by oversewing an aortic homograft. It was felt that the patient did not have typical coarctation but rather a mild congenital narrowing at the aortic isthmus which had become almost completely occluded by secondary atherosclerotic change (Flynn and Kattus, 1959). Though atherosclerosis is more severe in the aorta proximal to a coarctation (Clagget, Kirklin, and Edwards, 1954; Dunnill, I959), such advanced change in a young woman is most unusual.

Cystic medial necrosis frequently involves the ascending aorta but is usually associated with dilatation and aortic incompetence secondary to dilatation of the valve ring. Calcification in the aorta is rare (Eisen and Elliot, 1968; McKusick, 1960) and aortic stenosis does not occur.

Calcification of the aorta may also occur late in Takayasu's disease (Hachiya, 1970). Since Takayasu's disease involves mainly the arch and descending thoracic aorta, these are the regions most commonly calcified (British Medical fournal, 1969; Basu, I96I; Birke, Ejrup, and Olhagen, 1957; Cheitlin and Carter, 1956; Gillanders and Strachan, 1965; Gotsman, Beck, and Schrire, r967; Hachiya, 1970; McKusick, 1962; Mengis, Dublier, and Barry, 1958; Yamada et al., 196I). Only rarely does 
the calcification extend into the ascending aorta (Cheitlin and Carter, 1965; Schrire and Asherson, 1964; Yamada et al., 196I). As in syphilitic aortitis the calcification is intimal in atherosclerotic plaques complicating the aortitis (Ask-Upmark and Fajers, 1956; Boström and Hassler, 1965; Gould, 1968; Lessof and Glynn, 1959; Yamada et al., 196r). Judge et al. (1962) have reported a case of Takayasu's arteritis in which, in addition to involvement of the aortic arch and great vessels, the disease process extended into the ascending aorta, sinuses of Valsalva, coronary ostia, and aortic valve. Aortic incompetence had been present in life. Calcification was not present in the necropsy material.

An aortitis resembling that of syphilis histologically has also been described in ankylosing spondylitis. Though described initially by Mallory (1936), the association with spondylitis was first recognized by Bauer, Clark, and Kulka (I95I). In most of these cases the changes spread for not more than a few centimetres into the ascending aorta (Crow, 1960), though they may extend to below the renal arteries (Ansell, Bywaters, and Doniach, 1958). Aortic incompetence may occur, but aortic stenosis and calcification have not been reported.

There are a few reports of involvement of the aorta in rheumatoid arthritis (Sandring and Welin, 196I; Zvaifler and Weintraub, 1963). Necropsy in 2 of these cases showed the presence of rheumatoid granulomata in the myocardium, aortitis, and dilatation of the aortic root without involvement of the valve leaflets. Cathcart and Spodick (1962), however, have reported one patient with thickening of the aortic and mitral valves at necropsy, and another with calcification and thickening of the annulus of the aortic valve attributed to rheumatoid arthritis. Munasinghe and Rajasuriya (1966) described an I8-year-old Indian man with rheumatoid arthritis and extensive calcification of the aortic arch and descending thoracic aorta visible on $x$-rays. There was no evidence of involvement of the ascending aorta or aortic valve. Since the patient also had diminished left carotid and radial pulses, it seems likely that he also had Takayasu's disease. An association between Takayasu's disease and rheumatoid arthritis has been reported (Falicov and Cooney, 1964; Sandring and Welin, 1961).

Marquis et al. (I968) have pointed out that many idiopathic aortopathies and those associated with ankylosing spondylitis, rheumatoid arthritis, and other collagen diseases are essentially similar. For these cases, they have coined the term 'idiopathic medial aortopathy and arteriopathy', and in their paper describe 5 examples. Of these 3, patients presented with aortic incompetence, 2 secondary to dilatation of the ascending aorta and I due to in- volvement of the aortic valve leaflets. None had aortic stenosis or was associated with calcification.

It is clear that there is little or no evidence to indicate that any of the above diseases was responsible for the aortic calcification in our patients. Though the raised erythrocyte sedimentation rate in one patient, and the hypergammaglobulinaemia and false positive VDRL reaction in the other raise the possibility of underlying systemic disease.

We are most grateful to Dr. D. L. Watt for permission to publish Case 2.

\section{References}

Ansell, B. M., Bywaters, E. G. L., and Doniach, I. (1958). The aortic lesion of ankylosing spondylitis. British Heart Fournal, 20, 507.

Ask-Upmark, E., and Fajers, C. M. (1956). Further observations on Takayashu's syndrome. Acta Medica Scandinavica, 155, 275.

Basu, A. K. (196I). Occlusive disease of the aorta and its main branches. British fournal of Surgery, 49, 148.

Bauer, W., Clark, W. S., and Kulka, J. P. (195I). Aortitis and aortic endocarditis, an unrecognised manifestation of rheumatoid arthritis. Annals of the Rheumatic Diseases, 10, 470.

Birke, G., Ejrup, B., and Olhagen, B. (1957). Pulseless disease. A clinical analysis of ro cases. Angiology, 8, 433.

Boström, K., and Hassler, O. (1965). Takayasu's disease: post-mortem examination of a previously published case. Acta Medica Scandinavica, 178, 537.

British Medical fournal (1969). A case of aortitis with nephrotic syndrome, 2, 359 .

Cathcart, E. S., and Spodick, D. H. (1962). Rheumatoid heart disease. A study of the incidence and nature of cardiac lesions in rheumatoid arthritis. New England fournal of Medicine, 266, 959.

Cheitlin, M. D., and Carter, P. B. (1965). Takayashu's disease: unusual manifestations. Archives of Internal Medicine, 116, 283.

Clagget, O. T., Kirklin, J. W., and Edwards, J. E. (1954). Anatomic variations and pathologic changes in coarctation of the aorta. Surgery, Gynaecology and Obstetrics, 98, I03.

Cohen, J. A. (1970). Linear calcification of the ascending aorta without syphilis. Fournal of the American Medical Association, 214, 375.

Crow, R. S. (1960). Aortic incompetence in ankylosing spondylitis. British Medical fournal, 2, 271.

Dunnill, M. S. (1959). Histology of the aorta in coarctation. fournal of Pathology and Bacteriology, 78, 203.

Eisen, S., and Elliot, L. P. (1968). The roentgenology of cystic medial necrosis of the ascending aorta. Radiologic Clinics of North America, 6, 437.

Falicov, R. E., and Cooney, D. F. (I964). Takayasu's arteritis and rheumatoid arthritis: a case report. Archives of Internal Medicine, I14, 594.

Flynn, P. J., and Kattus, A. A. (1959). Coarctation of the aorta with proximal aortic dilatation and calcific atheromatous degeneration corrected by endarterectomy. Fournal of Thoracic and Cardiovascular Surgery, 38, 369.

Gillanders, L. A., and Strachan, R. W. (1965). The role of radiology in the diagnosis of Takayasu's arteriopathy ('pulseless disease'). Clinical Radiology, 16, Ir9.

Gotsman, M. S., Beck, W., and Schrire, V. (I967). Selective 
angiography in arteritis of the aorta and its major branches. Radiology, 88, 232.

Gould, S. E. (1968). Pathology of the Heart and Blood Vessels. 3rd ed., p. 967. Charles C. Thomas, Springfield, Illinois.

Hachiya, J. (1970). Current concepts of Takayasu's arteritis. Seminars in Roentgenology, 5, 245.

Jackman, J., and Lubert, M. (1945). The significance of calcification in the ascending aorta as observed roentgenologically. American fournal of Roentgenology, 53, 432.

Judge, R. D., Currier, R. D., Gracie, W. A., and Figley, M. M. (I962). Takayasu's arteritis and the aortic arch syndrome. American fournal of Medicine, 32, 379.

Leighton, R. S. (1948). Calcification of the ascending aorta as a sign of syphilitic aortitis. Radiology, 51, 257.

Lessof, M. H., and Glynn, L. E. (1959). The pulseless syndrome. Lancet, 1, 799.

McCann, J. S., and Porter, D. C. (1956). Calcification of the aorta as an aid to the diagnosis of syphilis. British Medical fournal, $\mathbf{x}, 826$.

McKusick, V. A. (1960). Hereditable Disorders of Connective Tissue, 2nd ed. C. V. Mosby, St. Louis.

McKusick, V. A. (1962). A form of vascular disease relatively frequent in the orient. American Heart fournal, 63, 57.

Mallory, T. B. (1936). Cabot case number 22141. New England fournal of Medicine, 214, 690.

Marquis, Y., Richardson, J. B., Ritchie, A. C., and Wigle, E. D. (1968). Idiopathic medial aortopathy and arteriopathy. American fournal of Medicine, 44, 939.

Mengis, C. L., Dublier, W., and Barry, K. G. (1958). The aortic arch syndrome of Takayasu. American Heart fournal, $55,435$.

Munasinghe, D. R., and Rajasuriya, K. (1966). Calcification of the aorta and main vessels in rheumatoid arthritis. American Heart fournal, 71, 813.

O'Sullivan, W. D., and Glenn, F. (1955). Contraindications to the surgical therapy of coarctation of the aorta. Annals of Surgery, 142, 909.

Sandring, H., and Welin, G. (196r). Aortic arch syndrome with special reference to rheumatoid arteritis. Acta Medica Scandinavica, I70, $\mathbf{I}$.

Schrire, V., and Asherson, R. A. (1964). Arteritis of the aorta and its major branches. Quarterly fournal of Medicine, 33, 439.

Smith, W. G., and Leonard, J. C. (1959). The radiological features of syphilitic aortic incompetence. British Heart Fournal, 21, 162.

Steinberg, I. (1966). Calcified and dilated ascending aorta due to atheromatous occlusive disease simulating coarctation of the aorta. American fournal of Roentgenology, 98, 840.

Thorner, M. C., and Carter, R. A. (1948). Roentgenologic diagnosis of syphilitic cardiovascular disease. American Practitioner, 2, 30I.
Wolkin, A. (1954). The significance of calcification of the ascending portion of the aortic arch. Radiology, 62, ror.

Yamada, H., Harumi, K., Ohta, A., Nomura, T., Okada, R., and Ishii, M. (196I). Aortic arch syndrome with cardiomegaly and aortic calcification. fapanese Heart fournal, 2, 538.

Zvaifler, N. J., and Weintraub, A. M. (1963). Aortitis and aortic insufficiency in the chronic rheumatic disorders - a reappraisal. Arthritis and Rheumatism, 6, 241 .

Requests for reprints to Dr. M. J. McLoughlin, Department of Radiology, Toronto General Hospital, Toronto 2, Ontario M5G IL7, Canada.

\section{Addendum}

Since submitting this paper for publication Singleton and Merten (Pediatric Radiology (1973), I, 2), have described two female patients who died at ages 12 and 4, respectively, with extensive calcification of the ascending aorta and aortic arch similar to our cases. The first patient had calcific aortic stenosis and mitral regurgitation, the second calcific aortic stenosis, aortic regurgitation, and a persistent ductus arteriosus. Both had grossly abnormal dentitions and unusual radiographic changes in the bones of the hands which resembled those seen in severe anaemia.

Our first patient had normal teeth, dental, and bone radiographs. The second was edentulous after dental extractions, but $x$-rays showed considerably underdeveloped, unerrupted upper and right lower third molars. Radiographs of the hands revealed undermineralization of the bones, with thinning of the cortices. There were also small erosions of the tufts of the distal phalanges of the thumbs and index fingers, associated with very small flecks of calcification in the adjacent soft tissues. Skull $x$-rays were normal apart from thickening of the vault and mild hyperostosis frontalis interna, and $x$-rays of the spine and pelvis were also normal.

Singleton and Merten's patients were physically underdeveloped and had febrile illnesses in early childhood followed by muscular weakness involving the lower extremities. Our patients gave no such history.

The aortic calcification in all these cases is remarkably similar and it seems likely that our second patient has a milder form of the condition described by Singleton and Merten. Our first patient with abnormalities restricted to the cardiovascular system may have a forme fruste. 